\title{
On the Construction of University's Financial Comprehensive Management System under Big Data
}

\author{
Xu ZhiChao ${ }^{1}$, Cao Yu², Li Yang ${ }^{3}$, Li ShuFen ${ }^{4 *}$, Song Ren ${ }^{5}$ \\ ${ }^{1}$ Jilin University of Finance and Economics, Changchun 130119 \\ ${ }^{2}$ Harbin Finance University Harbin 150000 \\ ${ }^{3}$ Jilin University of Finance and Economics, Changchun 130119 \\ ${ }^{4}$ Jilin University of Finance and Economics, Changchun 130119 \\ ${ }^{5}$ Jilin University of Finance and Economics, Changchun 130119
}

\begin{abstract}
In colleges and universities, financial work is not only related to the work and life of each teacher and student, but also related to the development of colleges and universities. In the era of big data, the accounting profession of colleges and universities is accompanied by the development of science and technology and network. The focus of its functions is from original cost-effective type to management type. The construction of financial comprehensive management systems in colleges and universities not only improves the efficiency of integrated information management in universities, but also strengthens the level of financial management to achieve a cashless accounting model; it can also improve the level of information construction in universities, strengthen the safety of financial payments, achieve transparency in official consumption, and contribute to the innovation and development of universities.
\end{abstract}

Keywords-Big data; Informatization;Financial comprehensive management system; Financial management; Cashless accounting

\section{INTRODUCTION}

In our country, as society continues to progress, innovation continues to develop, education continues to reform, and colleges and universities are expanding their enrollments year by year. In order to keep up with the current pace of development, the scale of colleges and universities is gradually expanding. The faculty strength must be continuously improved. Colleges and universities must be upgraded in terms of hardware and software so that they cannot be eliminated by the society.

With the advancement of science and the development of informatization, the era of big data has risen in waves of change in various fields. In colleges and universities, financial work has also entered the era of big data. The arrival of the information age has changed the way people live and changed the way all industries work. In such an environment, the financial work model of colleges and universities has also undergone a change. The content of work has been significantly expanded and extended, and information needs are also increasing, which exceeds the scope of traditional accounting. This requires university management departments to use "big data" thinking and technical science to construct a comprehensive financial management system for colleges and universities, create a scientific performance evaluation index system, enhance the effectiveness of use, prevent and monitor financial risks, optimize school resources, and improve school management [1].

\section{THE PURPOSE OF CONSTRUCTING COLLEGE FINANCIAL MANAGEMENT SYSTEM UNDER BIG DATA}

\section{A. Strengthen management level and reduce pressure of the financial staff}

Under the background of big data, colleges and universities build a financial comprehensive management system, and adopt a standardized and scientific method to control the overall planning and allocation of funds, so that financial management personnel can improve work efficiency and reduce work pressure.

\section{B. Regulate reimbursement process to facilitate the business management of teachers and students in the universities}

The financial comprehensive management system includes a lot of subsystems, it also contains a lot of business processes, face a variety of types of personnel, departments reimbursement issues, regulate the reimbursement process is an essential issue. With the standardized reimbursement process, teachers and students in universities are required to understand the materials needed for reimbursement and the steps for reimbursement, which will not only improve the efficiency of university work, but also increase the speed of business management for teachers and students in the universities.

\section{Improve service levels and clarify the future direction of university development}

In-depth analysis of the university's financial management system, continuous improvement of technology, continuous improvement of the module, and constantly improve services, so that the university's financial management system is more perfect, intelligent, and establish the basis for the rapid development of colleges and universities. 


\section{RESEARCH OF THE STATUS QUO OF DOMESTIC AND FOREIGN FINANCIAL COMPREHENSIVE MANAGEMENT SYSTEMS IN COLLEGES AND UNIVERSITIES}

\section{A. Research status of financial integrated management system in foreign universities}

In universities in developed countries, the financial integrated management system was basically established and integrated with multiple management subsystems. In the context of big data, this information transmission and feedback, information analysis and budget play an important role. Since the national conditions of each country are different and the country's financial requirements are different, the financial integrated management system built is also very different. However, the overall thinking and philosophy are the same, and they are all to be completed simply and conveniently. Work to improve the efficiency of management staff.

\section{B. Research status of financial integrated management system in domestic universities}

In China, many colleges and universities have achieved the digital management of the campus. The college's financial work also uses the campus network platform to basically realize online reimbursement, real-time inquiries, and accommodation and collection fees, which can dynamically control the operation of the college' $\mathrm{s}$ funds. However, there are still many deficiencies in the construction of financial information in colleges, which are mainly manifested in: (1) The information integration and sharing of financial management work is poor. (2) The decision support function of the financial management information system is weak. (3)The lack of comparability of the "two skins" of the budget and the pre-final accounts resulted in the weakening of the function of the financial management information system [2]

\section{THE MAIN CONTENTS OF FINANCIAL COMPREHENSIVE} MANAGEMENT IN COLLEGE CONSTRUCTION UNDER BIG DATA

\section{A. The main technology of financial integrated management} system

\section{1) Use firewall technology}

A firewall is also called a border firewall. It is a set of controls that implements access information between two (or more) networks and meets a certain security standard. Generally, it is a host or a router. A defense system that provides access between computers and external networks and can effectively control access to information and data between their computers and external networks. If the external network information data is handed over to the computer, the firewall must perform the judgment and analysis of the information data. If the input information data is found to be harmful, the transmission is directly cut off and the protection function of the computer is realized. [3]In colleges and universities, the purpose of building a financial integrated management system to design a firewall is to prevent those redundant, unauthorized information on the Internet from entering the private network, thus ensuring the security of the financial system [4]

\section{2) Adopt data security management model}

The financial integrated management system sets a user name and password to log in, encrypts data, strengthens storage control, limits access to the system's address, domain name, and permissions, and backs up various data in the system in a timely manner.

\section{B. The main contents of financial integrated management system}

According to the work situation of the university, the construction financial comprehensive management system is divided into the following subsystems: pay management subsystem, accounting subsystem, financial information query and reporting subsystem, self-service online repayment subsystem, and cashless report system, online payment and settlement subsystem, campus comprehensive budget management subsystem and special funds and project library management subsystem.

Self-service online reimbursement subsystem can realize the functions of loan business processing, daily reimbursement business, domestic travel business management, project authorization management, business document management, background definition maintenance, self-service receipt, and automatic certificate generation. And other special services can be customized features.

The cashless reimbursement subsystem can realize system login function, account query function, voucher system function, online payment function and bank card number intelligent matching function. 


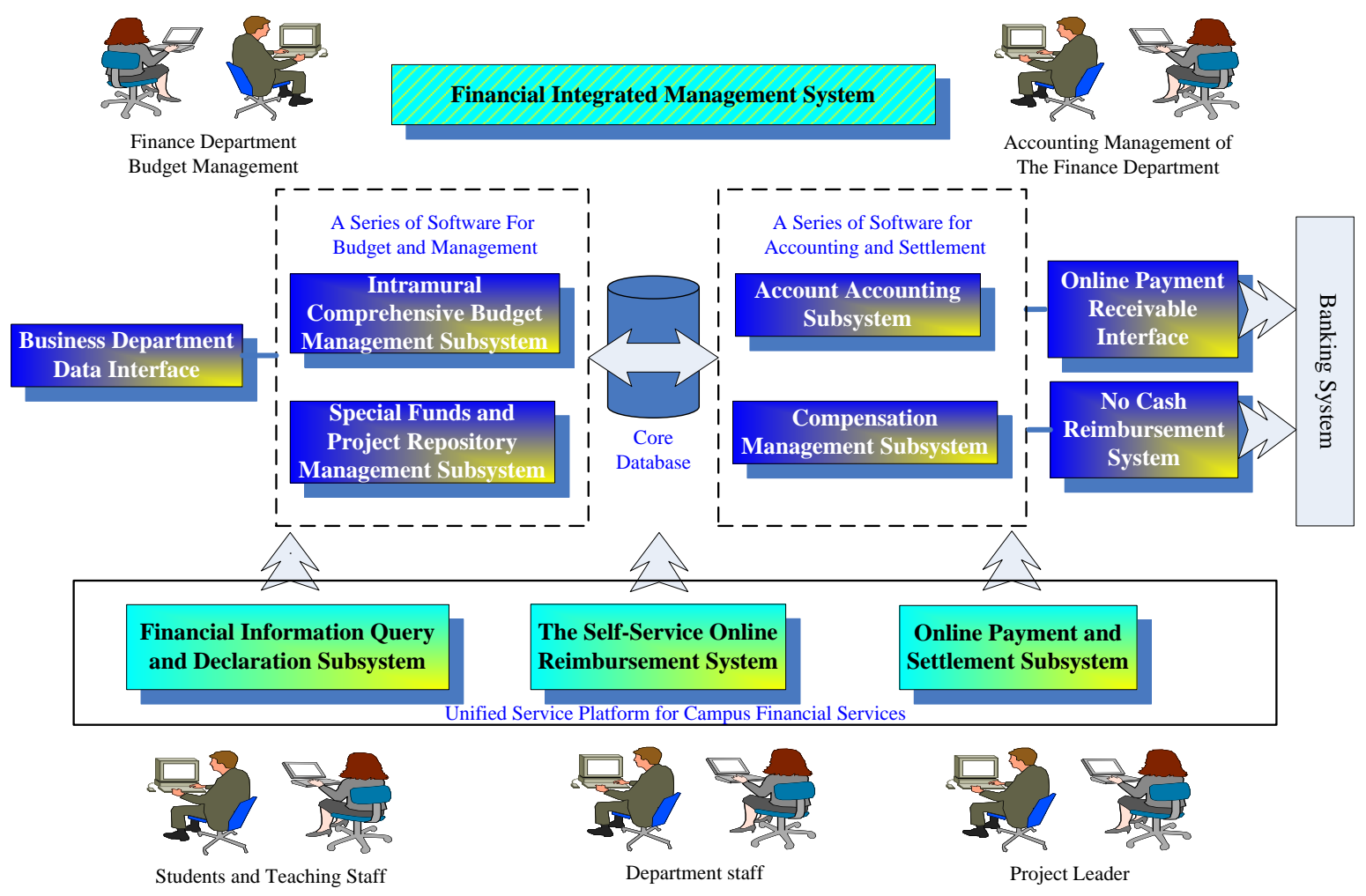

Fig. 1. As shown in the figure, the financial comprehensive management system module

The cashless reimbursement subsystem is the most useful module for teachers and students. Taking into account the safety and convenience of the system, we will introduce the detailed functions of this module.

The system login function can achieve the following functions, namely (1) Adopting intelligent non-driver-specific electronic tokens; (2) Hardware encryption, tamper-proof, and clone-proof design; (3) Without drivers and under any circumstances plug and play; (4)support two-factor triple authentication mechanism; (5) Support operator binding in the campus.

The account query function can implement the following functions, namely (1) Support for connecting multiple banks at the same time; (2) Support for multiple account balances and detailed inquiry; (3) Support for the binding of the school district account.

The voucher system function can realize the following functions: (1) Voucher system has two settlement modes, card payment and direct connection wire transfer; (2) Card payment support single or multiple accounts, peers or Inter-banking can be; (3) Direct-connected telegraphic transfer supports any combination of the bank's cross-bank, intra-city or off-site, public or private, single or multiple pen.

The online payment function can achieve the following functions, namely (1) Support selection of different bank accounts for payment; (2) Support for the binding of payment accounts in the sub-campus, support of the bank or interbank, city or offsite, public or private, single or multiple payment methods and any combination of them; (3) Inter-bank payment and immediate payment.

The smart bank matching function of the bank of communications can implement advanced algorithms based on semantic analysis. It can intelligently search banks according to the name of an unregulated bank, specify the bank to use once, and then use the system again to automatically search and match in the background without human intervention. The database of the bank number of the bank of 100,000 banks can be updated on a regular basis.

\section{The characteristics of financial integrated management system}

\section{1) Full-featured}

The system supports multi-bank, multi-account inquiry and payment; supports multi-campus management, each school district can bind operators, the school district can be bound to a specified account; also supports the bank or cross-bank, city or off-site, public or private, single or multiple payment methods and any combination of them.

\section{2) Easy to use}

The system can be based on job number, name first spelling, card number search card number dictionary, based on advanced semantic analysis algorithm, can intelligently search the bank according to the non-standard bank name, specify the bank once used, once again use the system to automatically search the background matching without human intervention. 


\section{3) High level security}

The system uses intelligent non-drive-specific electronic tokens, hardware encryption, tamper-resistant, anti-clone design, support for two-factor triple authentication mechanism, electronic tokens can store up to 100 hardware encrypted payment logs, and can be used in the event of accidents through professional the program reads.

\section{THE VALUE OF FINANCIAL INTEGRATED MANAGEMENT SYSTEM IN COLLEGES AND UNIVERSITIES UNDER BIG DATA}

With the reform of the education system and the implementation of the year-by-year expansion of colleges and universities, the number of undergraduates and postgraduates is increasing every year. The scale of running schools, the strength of teachers, and the level of running schools have increased, making all universities and colleges in terms of hardware and software facilities. All of them must be updated and improved accordingly. However, all of these require funding as support, and the school's financial management department needs to allocate funds rationally [5].

For colleges and universities, it is very important to realize information construction and platform model management. Combining with the actual situation of our university, the practical value of building an integrated financial management system is to improve work efficiency, better serve the people, analyze financial data under big data, and provide scientific decision support for the development planning and budget expenditure of universities.

\section{THE SIGNIFICANCE OF FINANCIAL INTEGRATED MANAGEMENT SYSTEM IN COLLEGES AND UNIVERSITIES UNDER BIG DATA}

With the advent of the era of big data, the tasks of financial management in colleges and universities have become more and more arduous, and the requirements for financial work in universities have become higher and higher. In terms of improving the efficiency of financial management in colleges and universities, the fine management of financial work is a very good measure [6].

In the context of big data, the construction of financial comprehensive management systems in colleges and universities is also required to advance with the times. The construction of financial comprehensive management systems will directly affect the efficiency and development prospects of colleges and universities. Therefore, we must vigorously promote the construction of the university's financial comprehensive management system, fully understand the financial work management process, establish an efficient, practical, and safe financial comprehensive management system, improve the strength of colleges and universities in the development of the new era, and promote the development of education in China.

\section{ACKNOWLEDGMENT}

This thesis is funded by the "13th Five-Year Plan" science and technology project of Jilin Provincial Department of Education "Exploration and Research on the Multidisciplinary Integrated Simulation Training Platform for Financial and Economic Colleges and Universities (Contract No.: JJKH20170122KJ)".

Foundation item: This paper is funded by the Jilin Province Social Science Fund Project "Human Resource Management Innovation Research of Service Enterprises in Jilin Province Based on the Perspective of Psychological Capital" (Contract No. 2017B75), Jilin University of Finance and Economics Project "Personal Capital Management Based Human Resource Management Innovation for Service Firms Study (Contract No. 2016P44)".

Fund Project: The paper is funded by the project of Educational Science Planning of Jilin province: Research on the application of "small tutorial system" in human resource management specialty (contract number: GH16257).

\section{REFERENCES}

[1] Li Xiuling. The Construction of University Financial Management Information System in Big Data Era[J]. Economic Research Guide, 2016(32):132-133.

[2] Cui Hongjun, Dang Jinquan, Huang Chengxing, et al. Construction of University Financial Management Information System in Big Data Era[J]. Finance and Accounting, 2015(31):113-115.

[3] Zhou Shujun. Analysis of campus network security technology-the application of firewall technology[J]. Information Systems Engineering, 2017(2):77-78.

[4] Lai Minfeng. Research on Financial Informationization in Colleges and Universities[J]. Finance and Accounting Communications, 2013(17):7072.

[5] Ling Dan. Design and Implementation of University Financial Management System[D]. Jilin University, 2015.

[6] Hu Fangfei. Research on the Fine Management of University Finance in the Era of Big Data[J]. Enterprise Reform and Management, 2016(1):142-142. 